Portland State University

PDXScholar

$5-22-2020$

\title{
Oregonian Holocaust Memory: Creating a Portal to the Past for Oregonians
}

Max Blust

Portland State University

Follow this and additional works at: https://pdxscholar.library.pdx.edu/honorstheses

Part of the Holocaust and Genocide Studies Commons, and the Jewish Studies Commons Let us know how access to this document benefits you.

\section{Recommended Citation}

Blust, Max, "Oregonian Holocaust Memory: Creating a Portal to the Past for Oregonians" (2020). University Honors Theses. Paper 884.

https://doi.org/10.15760/honors.905

This Thesis is brought to you for free and open access. It has been accepted for inclusion in University Honors Theses by an authorized administrator of PDXScholar. Please contact us if we can make this document more accessible: pdxscholar@pdx.edu. 


\title{
Oregonian Holocaust Memory: \\ Creating a portal to the past for Oregonians
}

\author{
by \\ Max Blust \\ An undergraduate honors thesis submitted in partial fulfillment of the \\ requirements for the degree of \\ Bachelor of Arts \\ in \\ University Honors \\ and \\ Judaic Studies \\ Thesis Adviser \\ Dr. Natan Meir
}

Portland State University

2020 


\section{Introduction}

You are walking along a paved pathway through a forest of fir and cedar trees in the Pacific Northwest. You arrive at a cobblestone square where there is a lamppost and a stone bench. The sky is ashen grey. You look down to see someone has dropped their glasses. You try to pick them up, but realize they are affixed to the ground and cold to the touch. You notice other items, such as a suitcase, a broken violin, a doll. There is no one there to claim these items, they are part of a memorial to victims of Nazi genocide which you have just stumbled upon. Each item represents possessions commonly left behind in the frenzy of deportations that took place during the Holocaust. You turn to your right to see concrete train track ties leading away from the town square, and you glide over them towards the Oregon Holocaust Memorial.

This memorial is situated in the front of Washington Park in Portland, Oregon. The space aims to convey a collective memory of the Holocaust which serves different purposes depending on the viewer. For those who have intimate connections to the Holocaust, the memorial is a place of solitude and remembrance where survivors and their families can gather. For those who have no connection to the Holocaust, lessons of tolerance and diversity are conveyed on the onyx panels of the memorial wall. For all, the memorial provides an experience that functions as a portal to the past, to portray to the viewer a constructed narrative of the genocide. But memory is not free. The memorial itself has a price, both financial and emotional. Constructing a collective memory of the Holocaust through a memorial carries a heavy financial burden, and exposing the subject of the Holocaust to public discussion leaves Jewish communities vulnerable to discrimination. Yet, the collective memory will be shown to be worthwhile enough to bear the brunt of this price.

Over 5,000 miles away from sites of persecution in Europe, the Oregon Holocaust Memorial (OHM) produces a memory which represents a narrative that attempts to be inclusive 
to all victims who shared an experience of deportation, annihilation, and camp incarceration. The genocide spanned 1933-1945 and reached its murderous height during the Second World War. The Holocaust was the planned murder of 6 million Jews, which swept away 5 million additional European minorities in the wave of violence. People were murdered through many cruel methods such as shooting, gassing, and creating conditions for disease and starvation to take hold. The Holocaust began in Germany in 1933 where discrimination against Jewish people was accomplished by stripping them of their civil rights. In the summer of 1939 the first murders began in the Nazi T4 program which killed people who faced disabilities, first by lethal injection, but later by gas. ${ }^{1}$ Once the Second World War began in 1939, oppression of Jews spread to the countries Germany occupied. As the German army advanced eastward in 1941, a commando group known as the Einsatszgruppen carried out the systematic murder of a million Jews by taking whole villages to nearby areas where they were shot into mass graves and buried. ${ }^{2}$

As Nazis sought to exploit and remove minorities from German society, isolated parts of towns and cities known as ghettos, as well as large fenced and guarded remote compounds known as concentration camps, were used as sites of incarceration for millions of deported European civilians. ${ }^{3}$ Deportations were a traumatic event in which Jews and other minorities were forced out of their homes with only as many belongings as they could carry and put onto trains to unknown destinations. Jews living all over Europe were rounded up and were often moved across borders by rail from their home countries to sites of incarceration. In transit, people were forced into the horrible conditions of a dark boxcar with no food, water, or facilities for multiple days. Once in camps and ghettos, people were subjected to harsh physical living

\footnotetext{
${ }^{1}$ Doris L. Bergen, The Holocaust: A Concise History (Rowman \& Littlefield, 2009),160.

2 Doris L. Bergen, The Holocaust: A Concise History (Rowman \& Littlefield, 2009), 195.

${ }^{3}$ Doris L. Bergen, The Holocaust: A Concise History (Rowman \& Littlefield, 2009), 146.
} 
conditions with little food or medical attention. Thousands died in these conditions. ${ }^{4}$ Those who remained alive in ghettos were eventually transported to concentration camps for slave labor or were sent directly to killing centers where they were murdered in gas chambers. ${ }^{5}$

There were six million Jewish victims of the Holocaust. To the Jews this genocide of just their people is known as the Shoah, meaning destruction. There were also hundreds of thousands of Roma victims of the Holocaust. Roma are often known as gypsies, but this term is in poor taste. To the Romani the genocide of their people within the Holocaust is known as Porraimos, meaning devouring. Millions of individuals including Jehovah’s Witnesses, homosexuals, and people with disabilities perished in the genocide. The Holocaust slowly came to an end, starting with the discovery of killing centers by the Russian Red army advancing through Poland. In Western Europe, British and American soldiers stumbled across box cars full of corpses, and abandoned concentration camps with thousands of people dying of disease and malnourishment. ${ }^{6}$ Survivors, those who lived through the Holocaust despite being part of a targeted group, continued to suffer for many years after liberation as they tried to recover from the physical and mental trauma of genocide. Their communities had been destroyed and most of their family members were gone. The vast majority of survivors would leave Europe forever, immigrating to join communities in Palestine and the United States. However, survivors spread as far as South Africa and Australia.

Jewish survivors of the Holocaust spread out across the world and were fortunate enough to resettle in places where there already were strong Jewish communities. Survivors arriving at Oregon found there was already a Jewish community that was nearing its centennial at the end of

\footnotetext{
${ }^{4}$ Doris L. Bergen, The Holocaust: A Concise History (Rowman \& Littlefield, 2009), 149.

${ }^{5}$ Doris L. Bergen, The Holocaust: A Concise History (Rowman \& Littlefield, 2009), 245.

${ }^{6}$ Doris L. Bergen, The Holocaust: A Concise History (Rowman \& Littlefield, 2009), 301.
} 
the Second World War. Jews were among the first European settlers to arrive in the Oregon territory, which allowed them to be widely accepted amongst other settlers and able to become leaders in their communities. ${ }^{7}$ In each of the places Jewish survivors settled, they carried their memory of the Holocaust, which was for a long time too painful to share. But when stories were ready to be told, survivors worked to create memorials in their adopted homes to serve as vehicles of a reconstructed recollection of the Holocaust. Hundreds of memorials recalling the tragedy of the Holocaust appear in dozens of countries around the world. The United States is one of many countries that built memorials to the Holocaust, with memorials appearing in major American cities from the Atlantic seaboard to the Western Pacific Coast.

As a major American city, Portland Oregon has followed the trend of establishing a Holocaust memorial. The Oregon Holocaust Memorial (OHM) carries a constructed narrative of the past through the presentation of testimony, remains, and design, which transport viewers to a space made relevant to the genocide.

\section{Collective Memory}

The Oregon Holocaust Memorial (OHM) is the conduit between individual memory and collective memory of the Holocaust in Oregon. The OHM evokes a recollection of a trauma, serving to cement a specific perspective of events into the physical monument. Collective memory is a common understanding of a past that is relevant to the community. It is used as a tool that serves to bring individuals into groups through the act of remembering together. ${ }^{8}$ Individual memory is transformed into collective memory through social structures. This is

\footnotetext{
${ }^{7}$ Eisenberg, Ellen. Embracing a Western Identity: Jewish Oregonians, 1849-1950. Corvallis, OR: Oregon State University Press, 2015.

${ }^{8}$ Elizabeth Jelin, "Memory in the Contemporary World," in State Repression and Labors of Memory, 2003, 2.
} 
because individuals possess real memories of an event, which they pool together by using a social system of communication to share and reinterpret personal narratives into a collective understanding. In this process the collective memory might not be a mirror reflection of the individual memory, but instead is reshaped by the integration of other stories that are coming together to convey the meaning of an event. ${ }^{9}$ Additionally, social frameworks that carry memory forward are born out of a society which imbues memory with its own set of values and ideals. A collective memory is thus given a meaning, and parts of the individual's memory may be subsumed or excluded depending on if it serves the meaning or not. ${ }^{10} \mathrm{~A}$ memory excluded is a memory forgotten. The end product of collective memory is less memory and more a shared recollection of an event. But when that shared story is told through a physical space such as a memorial, it creates a portal to the past where viewers can peer into a collective memory of an event.

How an event is preserved within a memorial will determine the collective memory produced and reflected upon by future generations. This is especially relevant to genocide. For those who have faced a traumatic event such as persecution, acts of remembering and forgetting are crucial for determining the lasting recollection of the event. ${ }^{11}$ The Oregonian Jewish survivors of the Holocaust came together with the intention of constructing a method to share their history with people who had not experienced the genocide, so that a collective memory of the Holocaust born out of their own experiences could be displayed with an intentional meaning. The physical Oregon Holocaust Memorial is now embedded with a collective memory of the Holocaust which is unique to Oregonians and shaped by how survivors in the community

\footnotetext{
${ }^{9}$ Elizabeth Jelin, "What Memories Are We Talking About?,” in State Repression and Labors of Memory, 2003, 24.

${ }^{10}$ Elizabeth Jelin, "What Memories Are We Talking About?,” in State Repression and Labors of Memory, 2003, 11.

${ }^{11}$ Elizabeth Jelin, “Memory in the Contemporary World," in State Repression and Labors of Memory, 2003, 5.
} 
experienced the genocide. Before going on to explore the design of the Oregon Holocaust Memorial, let us trace the historical roots of Holocaust memorials, to see how the genre developed to allow a memorial to exist in place so far from Europe.

\section{History of Holocaust Memorials}

While people were still perishing in the gas chambers of Auschwitz, a memorial was being set up to remember the victims of another concentration camp, Majdanek. This memorialization took the form of a pillar topped with three eagles and was built under the guise of a camp improvement project sanctioned by the German authorities. However, what the Polish artist and his comrades kept secret was that this was in fact a memorial to deceased friends who had been incarcerated. Human ashes were enclosed in the base of the memorial. The eagles atop this monument made it acceptable to the Germans, because the eagle was the national bird of Nazi Germany. However, the eagle was also the Polish national bird, and to the artist the three birds represented men, women, and children, going off into freedom. ${ }^{12}$ This was the first documented memorial to Holocaust victims, yet its meaning is not obvious since the true purpose had to be hidden to allow the memorial to exist as a false monument to the Third Reich. Obelisks and tall pylons were used in early memorials to mark the sites as meaningful, often leaving the meaning up to viewer discretion. Over the decades immediately following the war, memorials became more expensive and abstract with the intention of conjuring meaning and remembrance from the sites of destruction, as the horrors that took place slipped further back into time. In 1958 the memorial at Buchenwald Concentration Camp was completed as the first memorial complex, in which the memorial site encompassed the whole camp compound so that the space was

\footnotetext{
12 Marcuse, Harold. "Holocaust Memorials: The Emergence of a Genre,” The American Historical Review 115, no. 1 (2010): 57.
} 
preserved in its entirety as an homage to victims. ${ }^{13}$ The memorials, finally expressing themselves officially, began to construct unique memories of the Holocaust depending on the country in which they were built, the site's relevance to the genocide and the community that was remembering.

Memorials in Western Europe increasingly developed into avant-garde styles, in contrast to memorials in Eastern Europe which were dominated by Soviet heroicism of the Holocaust. Western memorials took on an experimental style featuring abstract symbols and artistic representation of victims and communities as well as manipulating space to create meaning. In France, avant-garde styles of Holocaust memorials arrived in 1960 with the building of a national memorial site at the Natzweiler-Struthof concentration camp in the far east of the country. The main monument is a curved stone fin that rises over 130ft into the air, and the fin displays a large outline of a frail human on the stone facade. ${ }^{14}$ Representing the individual victims and their communities is a significant marker for the genre of Holocaust memorials, as the creation of a memorial recovers the memory of victims and saves them from the second death of being forgotten. In Poland, at the former killing center of Treblinka, a memorial completed in 1964 is constructed in such a way as to manipulate space into the representation of a destroyed place, namely a Jewish cemetery. The memorial consists of grand granite blocks that form a three story tall tower and are surrounded by 17,000 shards of stone that evoke a Jewish cemetery. Many stones are inscribed with the names of Jewish communities destroyed in the Shoah. ${ }^{15}$

\footnotetext{
${ }^{13}$ Marcuse, Harold. "Holocaust Memorials: The Emergence of a Genre,” The American Historical Review 115, no. 1 (2010): 55.

${ }^{14}$ Marcuse, Harold. "Holocaust Memorials: The Emergence of a Genre," The American Historical Review 115, no. 1 (2010): 86.

${ }^{15}$ Marcuse, Harold. "Holocaust Memorials: The Emergence of a Genre,” The American Historical Review 115, no. 1 (2010): 87.
} 
While at first the altering of space was unique, it later became a central theme of many memorials outside of Europe.

A desire to memorialize the Holocaust was present in the United States as memorials were first being built in Europe. While there was not an official memorial recognizing victims of the Holocaust in the United States until decades after the Second World War, events in New York laid the ground work for American Holocaust memory. The first public American memorialization of the Holocaust came in 1942, while the genocide was still unfolding, and readily acknowledged the genocide as a Jewish event. On December 2nd, Jewish people in New York stopped work for ten minutes to commemorate those who had perished at the hands of the Nazis that year and to raise awareness of those who were still threatened. The Jewish Telegraph claimed that this was observed by five hundred thousand Jews in New York City. ${ }^{16}$ In 1944 , Mayor Fiorello La Guardia and Jewish leaders spoke to a crowd of some thirty thousand, honoring the first anniversary of the Warsaw ghetto uprising. ${ }^{17}$ While it was obvious during the Holocaust that the Jewish community may mourn and commemorate, the idea of long term public memorialization of the Holocaust in America was not planned until October 19th, 1947. At an event to unveil a permanent memorial site for remembering the genocide and ghetto resistance, Mayor William O’Dwyer spoke to ten thousand people all packed into Riverside Park to remember the Holocaust. He said, "It is fitting that a memorial to six million victims of the most tragic mass crime in history, the Nazi genocide of Jews, should rise in this land of liberty."18 Mayor O’Dwyer implied that since the U.S. is a free country, Americans would have

\footnotetext{
${ }^{16}$ James E Young, “America: Memory and the Politics of Identity,” in The Texture of Memory: Holocaust Memorials and Meaning (Yale University, 1993), 287.

17 James E Young, “America: Memory and the Politics of Identity," in The Texture of Memory: Holocaust Memorials and Meaning (Yale University, 1993), 288

${ }^{18}$ James E Young, “America: Memory and the Politics of Identity,” in The Texture of Memory: Holocaust Memorials and Meaning (Yale University, 1993), 289.
} 
the freedom to remember the Holocaust. But the memorial to serve as a remembrance site for Americans was never built. Only a stone slab with a message carved into it commemorating ghetto fighters and the six million Jewish victims of the genocide was placed on the site. A more elaborate memorial was never erected there, but another location would eventually serve to commemorate the genocide. At the New York location designated to be a memorial site, designs were either rejected or outright failed for a number of years when incorporating Jewish symbolism and allusion. In 1949, a proposed memorial featuring a rabbinic character was turned down with no comment. In 1951, a memorial representing the two tablets of the ten commandments, standing around six stories tall was proposed. However the project lost momentum after the artist's death. ${ }^{19}$ No memorial would ever come of these first plans, and the first large scale public memorial to the Holocaust in the United States wouldn't open until three decades later.

There is a clear disconnect between American Holocaust memorial sites and the events of the Holocaust, as opposed to memorial sites in Europe which are located where persecution took place. With no physical history to touch, American Holocaust memorials are shaped by American ideals and identity, which vary depending on where the memorial is built. The first American Holocaust memorials were built in significant locations relative to American history to place them into the national context, in order to compensate for their physical distance from the sites of destruction. The New England Holocaust Memorial significantly is situated along the the Freedom Trail, which sees millions of tourists a year and places the memorial spatially within the narrative of American revolutionary history. ${ }^{20}$ The United States Holocaust Museum and

\footnotetext{
${ }^{19}$ Marcuse, Harold. "Holocaust Memorials: The Emergence of a Genre,” The American Historical Review 115, no. 1 (2010): 53-89.

${ }^{20}$ James E Young, “America: Memory and the Politics of Identity,” in The Texture of Memory: Holocaust Memorials and Meaning (Yale University, 1993), 324.
} 
Memorial significantly is located along the National Mall, therefore setting the story of the Holocaust into the American narrative that is told through the dozens of other memorial sites and institutions that line the Mall.

In the 1980s, plans began for the New England Holocaust Memorial (NEHM) in Boston. While the new memorial would not depict the Jewishness as proposed in New York it recognized only the murder of six million Jews by the Nazis, not the murder of all 11 million minorities killed by the Nazis. The NEHM called itself a "Holocaust” memorial, but really represented just the Shoah. The Boston based memorial was not afraid to argue over the memory of the Holocaust and what would be depicted. ${ }^{21}$ The memorial committee hosted public debates on the merits and liabilities of the memorial. In these negotiations over where their public portal to the past would lead, many wanted to extend the scope of memory to non-Jewish victims of Nazi genocide, but this did not come to pass. ${ }^{22}$ Ultimately the memorial did not represent all of the memories of the Holocaust the public expressed, as is impossible for any memorial to do, and went with a well-known designer out of hundreds of entries. However, the process of public debate became the outlet from which different conceptions of the Holocaust flowed, and it gave evidence of the multitude of perspectives on the Holocaust that may conflict as they fail to align with one another.

As memorials spread westward across the United States there were more instances of a public construction of memory being interjected upon by those who saw the event of genocide from a different perspective. This was the case in the construction of the Babi Yar Park in Denver Colorado, which due to outcry by the local Ukrainians, included representation of

\footnotetext{
${ }^{21}$ James E Young, “America: Memory and the Politics of Identity,” in The Texture of Memory: Holocaust Memorials and Meaning (Yale University, 1993), 325.

22 James E Young, “America: Memory and the Politics of Identity,” in The Texture of Memory: Holocaust Memorials and Meaning (Yale University, 1993), 328.
} 
multiple mass killings of different ethnic minorities targeted during the Holocaust on one memorial site. ${ }^{23}$ By listening to the input of others who held claim to recollections of the Holocaust, the Denver memorial successfully constructed a collective memory of the Holocaust that was inclusive to more people. The creation of Holocaust memorials has not been straight forward processes, but rather arduous negotiations between those working to construct a historically representative collective memory of the genocide, and those who seek to put their own perspectives into those memories. Response from the public of any kind is an expression of a belief in what a public memory should include or exclude from a narrative of the Holocaust. While some say that we must create memorials that include the memory of victims from diverse backgrounds, others say we must exclude the perspectives of those who retell the Holocaust with bias from personal interest and antisemitic views.

In the Pacific Northwest, a memorial for the Holocaust was desired by many survivors who had been part of the Portland Oregon community for decades. In the city of Portland, similar expressions of memory played out as in Boston, in an attempt to shape the ultimately public collective memory constructed by the Oregon Holocaust Memorial. The gathering together of mostly Jewish survivors was the start of a ten-year process to create an educational memorial that delivered an inclusive collective memory and sought to allow individuals to connect with the story of the Holocaust regardless of their relation to it.

\section{The Oregon Holocaust Memorial}

In 1995, the coalition responsible for founding of the Oregon Holocaust Memorial came together. A group of Oregonian Holocaust survivors started the endeavor by recognizing a need

\footnotetext{
${ }^{23}$ James E Young, “America: Memory and the Politics of Identity,” in The Texture of Memory: Holocaust Memorials and Meaning (Yale University, 1993), 295.
} 
for an organization centered around victims and their descendants, which would further the memorialization of the Holocaust in Oregon for educational purposes. The organization would be called Oregon Holocaust Survivors, Refugees, and Families (OHSRF). A memorandum stated that the purpose of the organization was "to create and implement projects dedicated to, and in remembrance of, their family and the many millions who perished" and to build a supportive community that is committed to forwarding the message "Never again." 24 That same year, the Oregon chapter of the American Jewish Committee (AJC) became the umbrella organization for OHSRF. ${ }^{25}$ This marked survivors gaining a major supporter who would be a key ally during the turbulent decade that preceded the memorial's completion. Though it was a long process, the OHM was completed in 2004 in its ultimate location in Washington Park. The site was chosen in 1995 and contested in courts by the Arlington Heights Neighborhood Association, a neighborhood bordering Washington Park, until 2003.

Survivors and others impacted by the Holocaust are to thank for the memorial; by going on with their lives and sharing stories with their children and grandchildren, they have infused the Holocaust memory into the public memory. In the construction of collective memory, it is survivors who hold the firsthand accounts that are later reinterpreted and combined with other memories to become the narratives produced by memorials. The survivors are present in the memorial through the witness wall quotes which stand as testimony to genocide. The memorial also serves as a sacred final resting place, as it includes remains from major killing centers in Europe. Through the memorial committees' effort to broaden the scope of memory and include any survivors willing to become part of the project, the Romani people are included, a group that

\footnotetext{
24 “Letter - OHSRF and AJC,” 1995, Org 48 Oregon Holocaust Memorial, Box \#3 Series II: Construction, Construction: Agreements., OJMCHE.

25 “Letter - Judith Kahn,” 1995, Org 48 Oregon Holocaust Memorial, Box \#3 Series II: Construction, Construction: Agreements., OJMCHE.
} 
has been historically underrepresented in depictions of the Holocaust. The inscription wall bears important Romani names that give representation on the community's terms. It is significant for a project mostly backed by one group, the Jewish community, to extend such an offering to another ethnic community and ask nothing in return. It is clear that what the Jewish community gains in including the memory of Romani people is having a more diverse representation, so that the lessons of the Holocaust will be transmitted through a broad collective memory of genocide.

\section{Designing the Oregon Holocaust Memorial}

The Oregon Holocaust Memorial design team was responsible for conceptualizing the memorial in the Wright Avenue site donated by the city in 1995. The design team was made up of six members, Ted Savinar, Marlene Salon, John Warner, Paul Sutinen, Marshall Lee, and John Laursen. Savinar was the most accomplished designer and considered the lead on the project, as he had just recently designed the memorial for the mass shooting at Columbine. At both the Columbine memorial and the Oregon Holocaust Memorial, Savinar worked to give visitors a personal experience in a public place. Savinar held the view that, for those who seek remembrance, it is hard but worthwhile to overcome a desire for a multitude of memorial features and instead focus solely on the question of "what you want people to feel like, not only now, but after all of us are dead.”26 Instead of centering on an extensive experience, Savinar focuses on what emotions to evoke in people through their recollection of the genocide. The design process took place between '95 and '96. The plan received resounding approval, especially from the Memorial Coalitions Art Council, which unanimously voted in favor of the

\footnotetext{
${ }^{26}$ Randy Gragg, "Savinar: Interviews with Relatives Part of the Design,” The Oregonian, April 9, 2003, OJMCHE Archive.
} 
design after it was submitted on June 28th, $1996 .{ }^{27}$ The memorial was built to the wishes of the original proposal, despite the eight-year delay due to strength of the design. The design's success signals how well the memorial's planners had constructed an inclusive collective memory of the Holocaust. These designers were specific in planning for what objects and aspects of the memorial as well as the natural space around it would evoke the constructed narrative of the Holocaust. While some spaces are designed to be jarring, others play the role of inciting reflection on the event or remembrance of the victims. In the written plans for the memorial, the following connections are made between aspects of the memorial and intended meanings. Boulders and gravel rocks are to convey remembrance, while the walkways and benches are to be contemplative. Historical writings are to be educational, and an eternal flame and landscaping are to instill feelings of hope for the future. ${ }^{28}$ Out of all the original memorial features conceived by the team, only an eternal flame was left entirely out of the memorial.

The design that Savinar and his team proposed, and ultimately became the completed memorial, can be broken down into five distinct sections. First, the town square serves the purpose of transporting Oregonians away from Portland and into a space where they can imagine the Holocaust and engage with the subject in a relevant place. Second, the witness wall portrays survivors' direct memories from the Holocaust. Third, the soil vault, where soil from all six killing centers were placed by survivors, is buried under an onyx column that is inscribed with names of six sites of destruction and recognizes the remains present. Fourth, the memory wall has the names of victims of the Holocaust who are related to Oregonian survivors which provides a place of quiet reflection as one reads the hundreds of names present. Fifth and finally,

\footnotetext{
27 “OHSRAF Concepts for Artists and Architects,” 1996, \#48 Box \#3, OHM Construction, Construction: Art Committee, OJMCHE.

28 “OHSRAF Concepts for Artists and Architects,” 1997, \#48 Oregon Holocaust Memorial Box \#3, OHM Construction, Construction: Art Committee, OJMCHE.
} 
the concluding panel gives lessons to take away from the story told of the Holocaust by the memorial, and recognizes by tribal names some of the Romani people murdered by the Nazis.

\section{The Town Square}

The town square consists of a cobblestone square with a lamppost and bench to resemble a European square. The designers' purpose was for the bronze items to "suggest the scattered remains of a hasty exit, the crying voices of children hurried in tow and the loss of personal objects that signify family and home.”29 This space serves the purpose of transporting the person away from Oregon and into a constructed memory of Hitler's Europe, so as to tell the story of the Holocaust. This story begins at deportation, when hundreds of thousands of Europeans were abruptly forced to leave their homes and only bring a small number of their personal possessions with them. Most were never to return. The bronze objects represent what was left behind, dropped in the rush of forced deportation. They are everyday items that are intended to remind a viewer of themes of family. The doll and child's shoe represents children within the family, while items like the glasses and the suitcase represent adults within the family. These divisions are often pointed out in genocide studies because the murder of children physically wipes out the most recent generation of a group. 1.5 million children were murdered in the Holocaust: one million, five hundred thousand futures and dreams never fulfilled. The ultimate tragedy for any group is the loss of their youth. The bronze broken violin conjures memories of the great artists and musicians whose work was left unfinished as they were deported from sites such as Theresienstadt ghetto to killing centers. The bronze broken Hanukkah Menorah is the only overtly Jewish item, and has the purpose of drawing in a viewer with a well-known Jewish

\footnotetext{
29 “Design of the Oregon Holocaust Memorial Garden,” 1999, \#48 Box \#4, OHM Construction, Construction: Design Team.
} 
American symbol, which represents the fractured religious communities of Jews in the wake of the deportations during the Holocaust. Leading away from the square and towards the Memorial wall, representations of concrete train track ties are sunken into the path so while walking you pass over them as if on a train heading towards sites of destruction. This space uses design to evoke a setting of genocide, with the purpose of moving the audience into the memorial and to descriptions of persecution on the memorial's history wall.

\section{The Witness Wall}

On the outward facing side of the memorial wall, fourteen plaques are inset into the stone facade, each with a different quote from a survivor. The quotes show experiences ranging from normal life before the Holocaust, deportations, extermination camps, and fractured family life. Short yet revealing quotes capture normal life and the shift away from it towards a life of persecution. A plaque reads, "I can remember a sweet and simple little painting of a bowl of fruit hanging above my parents bed.” Simple details of universal themes of home allow many people to relate to a normal life experience that victims had before the Holocaust, therefore affirming within the collective memory that victims were ordinary people just like the viewer. One quote reads; “We had friends and parties and concerts in the park. I could hardly wait for my tenth birthday when I was promised a new pair of ice skates. A few days before that birthday my whole world changed.” This line captures a once normal life being interrupted by the Holocaust, never to be the same again. The abnormal circumstances are marked with dramatic events of deportation and the arrival at killing centers, which ended the journey for so many people.

Quotes from survivors that pertain to themes such as deportation use memory to construct a narrative that depicts a journey to the gates of Auschwitz, and the horrors within. One quote shows a memory of deportation and transit to killing centers explaining that it was "three days 
and two nights all of us locked in a boxcar with a bucket, a single bucket in the middle of the floor. The train ride was miserable - a stinking filthy revolting pestilent mess. And when they opened the doors we found ourselves in hell.” The transit to incarceration sites is an experience many Holocaust victims had, both Jews and non-Jews, which again makes it an example of broad depictions of genocide for the sake of inclusivity.

The transportation of victims by train is an infamous part of the Holocaust, and has been commonly depicted in films, such as Schindler's List, to represent the destruction of the Jews. In his memoir, Night, Ellie Wiesel wrote extensively about traumatic experiences while being moved from his home to Auschwitz in a box car. Wiesel won the Nobel Peace Prize in 1986 and his book Night has been one of the most influential Holocaust texts of all time, second only to the Diary of Anne Frank. In 2006, Night became a best seller again, after Oprah Winfrey chose it for her televised book club. ${ }^{30}$ His story of deportation and transit is so well known that such themes came to be called upon and recognized by an audience.

Within the quotes there are few representations of lesser known pieces of the genocide, such as the murders carried out by the Einsatzgruppen in Eastern Europe and Russia. Over a million of the murdered Jews never entered into a boxcar, but instead were moved by foot or truck to areas near where they lived and were shot into pits. This horrible way in which people were murdered is not depicted because it is not a story that is part of Oregonian survivors' memories, and is absent from American memories, since it was a method of murder during the

\footnotetext{
${ }^{30}$ David Cohen, “Elie Wiesel, Holocaust Survivor, Activist and Nobel Peace Prize Winner, Dies at 87,” POLITICO, accessed May 21, 2020, https://www.politico.com/story/2016/07/elie-wiesel-holocaust-survivor-activist-and-nobelpeace-prize-winner-dies-at-87-213655.
} 
Holocaust that has not been well introduced to the public through a widely publicized piece of literature or film, to date. ${ }^{31}$

The memorial recognizes that life before genocide is hard to return to, and that suffering from the past remains forever, as people live on without family and friends. One plaque reads, "I had a childhood in which there was no mother, no father, no brother, no sister, no grandparents, no cousins, no aunts, no uncles. To this day I am filled with envy when I see children walking hand-in-hand with their parents.” This survivor's memory of loss is conveyed to us as part of a collective memory of the Holocaust, giving a broad scope of victims through the inclusion of many family members' titles. Quotes such as “The fear has never left me” shows the lifelong impact the trauma of experiencing genocide has on the psyche. Together the survivor quotes construct a collective memory of the Holocaust which is unique to them and their recollection of experiences in Europe.

\section{The Soil Vault}

Underneath the end of the memorial wall sits the soil vault. On an onyx panel it is stated that "Beneath this rock are interred soil and ash from the six killing-center camps of the Holocaust" and below the sites are listed: Chelmno. Treblinka. Sobibor. Belzec. Majdanek. AuschwitzBirkenau. The six centers are responsible for the killing of over three million Jews, including hundreds of family members of survivors who would eventually rebuild their lives in Oregon. By placing the remains of victims at the site, the sacredness of the place increases as it becomes a final resting place for victims. The memorial wall and soil vault themselves serve as a grave site for mourning the victims who beforehand had no recognized final resting place. Many of the

\footnotetext{
${ }^{31}$ Izabella Tabarovsky, “Auschwitz Cannot Be Only Pillar In Holocaust Memory - The Forward,” June 12, 2019, https://forward.com/opinion/425672/not-all-jews-were-killed-in-concentration-camps-during-the-holocaustwe/?fbclid=IwAR2BqIC76e2HLtfJcxjntvjYPbqbbggFZ9MxRTktnOToxdasf16rkAulXqc.
} 
survivors that eventually came to Oregon were interned in the final and largest camp, AuschwitzBirkenau. Oregonian survivor Miriam Greenstein was imprisoned in a section of the Birkenau complex after the murder of her mother in the Auschwitz gas chambers. She later returned to all six killing centers with a group of other Oregonian survivors to collect ash to bring back to Oregon for the Soil Vault that would be part of the memorial. She documents this intrepid journey back to the sites of destruction in her book In the Shadow of Death. Greenstein describes the experience of returning to the camp that she was once a slave in, isolated in one area, and now being free to roam and see the vastness of the Birkenau complex. Greenstein writes that a short distance away at Auschwitz they "dug soil from a putrid pond directly across from one of the crematoria.” The grief of returning to reclaim the remains of one's relatives is beyond knowable, but what she says is that "The emotional stress left us barely functional." ${ }^{32}$ Because of the survivors' bravery to return to Europe and collect remains of their murdered family, the memorial is more connected to their existence and circumstances of their murder, as it bears the honor and burden of being the site to serve as their final resting place for all time. The camp Belzec was an especially deadly camp, as the survivors who were still alive after the Second World War can be counted on one hand. ${ }^{33}$ In her memoir Greenstein recalls visiting this killing center while it was raining. "We huddled under umbrellas, dug some soil, said the prayers, and left. This camp is one of the saddest places on this earth, definitely not somewhere to linger or sightsee. It left an indelible impact on my psyche." ${ }^{34}$ This memory of the killing center is drawn upon by the soil vault, which represents the sites of destruction and the dead. Under the stones of

\footnotetext{
${ }^{32}$ Miriam Greenstein, "Return To Auschwitz," in In The Shadow Of Death: A Young Girl's Survival in the Holocaust (Portland, OR: Press-22, 2010), 116.

${ }^{33}$ Doris L. Bergen, The Holocaust: A Concise History (Rowman \& Littlefield, 2009), 248.

${ }^{34}$ Miriam Greenstein, "Return To Auschwitz," in In The Shadow Of Death: A Young Girl's Survival in the Holocaust (Portland, OR: Press-22, 2010), 113.
} 
the memorial are the remains of murdered individuals resting in neatly tied cloth bags with their sites written on the sides. Survivors themselves brought the memory of the killing centers into the construction of collective memory for the Holocaust.

\section{The Memorial Wall}

The Memorial wall, which has the names of over six hundred relatives of Oregonian survivors who were murdered in the Holocaust, is cause for deep reflection for those present. Significant effort went into the inscription process for the wall, to represent as many victims and survivors who have a connection to Oregon as possible. In 1997, the Oregon Holocaust Memorial Coalition (OHMC) had been active for a number of years and had already chosen a design to fit with the city allocated property along Wright Street in Washington Park. The memorial wall was to be on the back of the memorial's eight-foot-tall wall, where there would be onyx panels on which the names of victims related to Oregonians would be listed. Yet with no database of Oregonian Holocaust survivors and their deceased relatives, a committee had to be formed to find as many survivors as possible interested in sharing the names of their loved ones. This effort allowed for the memorial to become a more inclusive space than it may have been otherwise. By reaching out to survivors, both Jews and gentiles, the memorial coalition included the memory of the Great Devouring of the Roma people alongside the Shoah of the Jews. Both of these terms refer to different murders within the same genocide, each with the perspective of two separate peoples.

On October 22nd, 1997, at the organizational meeting for the Memorial Wall Committee it was decided that the best way to reach out to survivors was through the sponsors of Holocaust education and the memorial itself. On a document that would have been mailed out to survivors for information on their relatives, specific inscription guidelines were given. To qualify for your 
relative to have their names inscribed on the memorial free of charge, names had to be of immediate family members, including: children, parents, siblings, grandparents, cousins, aunts and uncles who perished in the Holocaust. Fifty letters would be inscribed for free. For additional names that were not covered by the category or were over fifty letters, there would be a cost of \$3 per letter. The due date to return inscription forms was March 1st, 1998, which gave individuals approximately four months to make names available. While the first 50 letters were free, this normally wasn't enough characters to remember every single murdered relative for each survivor free of charge. ${ }^{35}$ Thus survivors did have to at times pay for a more complete form of memorialization, but it did not bar people from including the memory of their family in the memorial.

On December 1st, 1997, The Jewish Review published an article alerting the Jewish community of the OHMC's pursuit for names of people murdered in the Holocaust for the new memorial. The article said that the Coalition was searching for survivors within Oregon and southwestern Washington. In the article, an interviewed member of the Coalition, Evelyn Thomas, "stressed that the OHMC views the victims of the Holocaust as anyone who perished in the camps from any cause.” ${ }^{36}$ The desire for the memorial to be inclusive is emphasized in the article, showing that the mostly Jewish effort sought to pull fellow victims' memories into the memorial. A few months later, Leland Robinson responded to the request for names as a representative of the Roma community through her leadership in the Pacific Northwest Chapter of the International Romani Union. After a number of intertribal discussions, Robinson says that

\footnotetext{
35 “Memorial Inscription Form” (OHMC, 1997), Org 48 Oregon Holocaust Memorial, Box \#5 Series II: Construction (1992-2004): Inscriptions.

36 “Memorial Seeks Names“ (The Jewish Review 1997) Org 48 Oregon Holocaust Memorial, Box \#5 Series II: Construction (1992-2004): Inscription Approvals.
} 
their "primary means of identification is tribal" 37 and offered two ways to incorporate the Roma into the Memorial. First in the town square, Robinson asked that a little inscription plaque be made that says "In memory of the Roma (Gypsies) who died in the Holocaust.” For the memorial, the tribal names Sa Roma, Kalderasha, Romanichal, Machwaya, and Boyash are requested to be inscribed on the memory wall. While Robinson's first request would go unfulfilled, the second request of the inclusion of the tribal names was adamantly taken on by the memorial coalition. On April 22nd, 1998, the inscription commission put out a progress report on how many names had been received for inscription. The report recounts sending out 300 inscription forms by mail to survivor contacts often made through Jewish partners and supporters. At the writing of the report, there were 123 responses received totaling more than 573 names for inscriptions. The report mentions that "Some people have been reluctant to submit names at all because of the delays and confusion created by the site dispute.” The report states that the attempts to identify Oregonians who have Jehovah's Witnesses relatives who died in the Holocaust was unsuccessful in spite of local and national attempts by Witnesses organizations. ${ }^{38}$ In the end, the Roma were represented in the concluding text of the memorial, and Jehovah Witnesses were mentioned but not in great detail since the Portland community lacked Witness survivors or relatives. ${ }^{39}$ On the memorial, the Roma's experience of persecution is depicted and the tribal names that were first requested to be included in 1998 are present in the inscription. The text reads: "Descendant of Roma tribal groups - the Bashaldey, the Boyash, the Kalderasha, the Machwaya, the Romanichal, and the Sa Roma - live among us here in our own community.

\footnotetext{
37 “Letter - Robinson 98” (OHMC, 1998), Org 48 Oregon Holocaust Memorial, Box \#5 Series II: Construction (1992-2004): Inscription Approvals.

38 “Inscription Progress Report” (OHMC, 1998), Org 48 Oregon Holocaust Memorial, Box \#5 Series II:

Construction (1992-2004): Inscription Outreach

39 “Inscription Progress Report."
} 
They too cherish the memory of loved ones lost at the hands of the Nazis.” (The Oregon Holocaust Memorial).

After the memorial opened in 2004, Leland Robinson sent a second letter to Emily Gottfried, a well-known figure in the Jewish Community. The letter gives thanks “for including... various tribal groups in the memorial wall concluding text.” The letter gives an interesting Romani perspective that "the Holocaust became known as Porraimos which means the Great Devouring. Regardless of the name it was the same event of Nazi genocide.” For the Roma, a mostly unrecognized people, the small inscription on the memorial was a little piece of recognition, after living for fifty years with unrecognized and "unresolved historical grief.”40 Despite the majority Jewish financial backers of the memorial, a narrative was constructed of the Holocaust that reflected the diversity of victims, as opposed to focusing on only the 6 million Jewish victims.

\section{The Rare Dissent to the Oregon Holocaust Memorial}

The Oregon Jewish Museum and Center for Holocaust Education (OJMCHE) archive has preserved a collection of letters both supporting and dissenting to the memorialization of the Holocaust in the State of Oregon. These letters were sent to the Oregon Holocaust Memorial Coalition while planning and permitting for the memorial were taking place. Messages of support make up the vast majority of the letters that were sent to the coalition. During the design proposal and construction, prominent Oregonians, such as senator Mark O. Hatfield and mayor Vera Katz, wrote in to show their interest in the project continuing forward. After the memorial

\footnotetext{
40 “Letter - Robinson 04” 2004, Org 48 Oregon Holocaust Memorial, Box \#5 Series II: Construction (1992-2004): Inscription Approvals.
} 
was completed in 2004, a number of school children who visited the new memory site wrote messages depicting what they enjoyed about the memorial and the lessons of tolerance that they took away. Additionally, over two dozen letters are saved in the OJMCHE archive that are addressed to commissioner Charles Jordan. They express opposition to his 1998 decision to rereview the Washington Park site for the Holocaust memorial, despite the City Council unanimously agreeing to use the site for the memorial in 1995. These letters call out local officials for slowing down the process and by being willing to listen to the complaints of Arlington Heights neighbors framing the debate as if it had yet to be decided, when in fact the site has already been given to the memorial. ${ }^{41}$ The letters are by community members and educators who see the Holocaust as relevant to Oregon history and worthwhile to produce a collective memory of the event.

Not all the letters to the memorial coalition were to give respect and admiration for the project; letters sent in by members of the Arlington Heights neighborhood paint the memorial as a threat to their community due to fears over parking and traffic congestion. However these letters express a desire to relocate the memorial to other public grounds they deem more appropriate for reasons unrelated to discrimination. However, a few letters and opinions from Portlanders utilize antisemitic rhetoric to argue that the very existence of a memorial honoring the Holocaust on public land is discriminatory. A letter by Mr. Paul Seely is titled "Are Jews Better or More Important than Other Ethnic Groups?” The writing embodies a resentful and discriminatory view of Jews that paints the memorial as exclusionary. Mr. Seely starts his letter by asking "Has anyone noticed that the projected design of the memorial exalts one particular

\footnotetext{
41 “Letters of Support - to Comissioner Jordan 1998,” 1998., Org 48 Oregon Holocaust Memorial, Box \#9 Series II: Construction (1998-2004), Construction: Site Selection - Letters of Support.
} 
ethnic group above all others, implicitly saying that other genocides besides that of the Jews are not really as important?” He goes on to say “if the city really cares about the interest of all ethnic groups equally, this memorial should either be radically revised to give other holocausts equal emphasis and space (the truly ethical solution) or built with its bias on private property." ${ }^{42} \mathrm{Mr}$. Seely bases his perspective on antisemitic tropes that Jews are in a position of power and supremacy compared to non-Jews. Seely's statements further show he has little knowledge of the project's inclusive message and the goal to bring together as many victim groups of the Holocaust to commemorate as possible, not just the Jews. He makes the argument that because we are not remembering other genocides we cannot remember the Holocaust, because that is to elevate one group's experience above others. Seely does not recognize the fact that hundreds of Holocaust survivors made their homes in Oregon and became part of the community for decades. Seely's expression of opinion serves the purpose of shifting memory of the Holocaust to one of the Jews tragedy used as supremacy over other groups. The reason there is a memorial is because the United States gave opportunities for survivors of the Nazi genocide to reestablish their lives in North America after the Second World War. Victims of other genocides have not been given such opportunities by the United States, since Americans have yet to be closely connected to another genocide in the way they were as liberators and witnesses to victims of the Holocaust. After surviving genocide, 150,000 Jews lived in displaced person camps in the U.S. zone of divided Europe alone. Jewish survivors waited for visas to be able to join other Jews in already well established communities off of the European continent, in the United States, Canada, or Australia. ${ }^{43}$ Such was the case for many Jewish survivors arriving to safety in Oregon.

\footnotetext{
${ }^{42}$ Seely, "Letter - Are Jews Better or More Important than Other Ethnic Groups? An Open Letter to the Oregon Holocaust Memorial Coalition, the City Council and Others.," 1998, ORG 48 Box \#1, OHM Series I: AdminCorrespondence: Letters in Opposition, OJMCHE Archive.

43 Doris L. Bergen, The Holocaust: A Concise History (Rowman \& Littlefield, 2009), 305.
} 
One memory of the Holocaust expressed by a survivor saw the value of the memory, but understood it to have no place in Oregon. The notable letter was sent in response to a request for inscriptions from Holocaust survivor Laureen Nussbaum. This brief hand written note is signed by both her and her husband, a fellow survivor, and rejects memorializing the Holocaust in Oregon, based on it being misfitting in their view. Nussbaum writes, "We do not believe that Portland OR is a proper place to set up a memorial for Holocaust victims, that should be done and is being done in Germany and in the countries formally occupied by the Nazis." 44 This perspective cannot be rationalized as being based on antisemitic belief, since to the Nussbaums, the Holocaust is not a vicarious memory they share with thousands, but personal memories that are to never leave them. It must be accepted with no further inquiry, that to some survivors, the Holocaust was such a traumatic event a desire remains for distance from the memory and thus they may reject a collective memory which would further burden them. From the Nussbaums’ perspective, there is exasperation from having come so far from Europe to leave behind challenging memories only to have them be conjured up again by the new public they have come to be a part of. Fortunately for the Nussbaums, the OHM is in a secluded area that must be visited intentionally and can thus be avoided. While the Nussbaum's request for the memorials to be kept in sites of destruction is valid, so too was the desire that many survivors had for a location to remember their murdered relatives. Ultimately the desire to construct such a space prevailed, although not without significant costs.

\section{The Price of Memory}

What is significant about the antisemitic dissent to the Oregon Holocaust Memorial is how infrequently it emerged throughout the process of its construction. Besides the Seely letter and

44 “Letter - Nussbaum.” (Nussbaum, 1998) Org 48 Oregon Holocaust Memorial, Box \#5 Series II: Construction (1992-2004): Inscription Approval. 
one unremarkable published comment, there are no other memorable antisemitic comments about the memorial, and the main source of resistance is seen as coming from folks with a Not in My Backyard mentality who did not want to give up a space that was near their residences for a memorial. The fact that this was a mostly Jewish funded project given public land and allowed to establish a memorial, shows that Jews are an accepted community within Oregon. Jewish Oregonians feel the freedom to publicly express their history as they are recognized as an influential part of the public. The Jews of Portland are confident enough that they were willing to reach out for fellow victims of the Holocaust to include them in the narrative they were constructing so as to be as broad and inclusive as possible. This confidence was present in the Portland Jewish community at the establishment of the memorial in 2004, however opinions and views of the Jewish community are not static. Antisemitism has become more prevalent in Portland over the past decade. In 2016, the statue of Portland Mayor and Jewish Holocaust survivor Vera Katz was defaced with a swastika. ${ }^{45}$ While Jews have yet to feel physically threatened in Portland, high profile hate crimes such as the 2017 Portland train attack, in which an act of hate ended in the killing of Taliesin Namkai-Meche and Ricky Best, have raised the profile of discrimination in the city. ${ }^{46}$ The memorial represents a period of time that might not be easy to return to, in which Jews were comfortable pursuing public memorialization for relatives who never lived in Oregon. Despite the uncertain discriminatory views that are present in Oregon, the state was ultimately built with the intense help of Jewish people who are intrinsically woven into the fabric of Oregon society. Jewish people are going to remain in Oregon, and so is

\footnotetext{
45 “Vera Katz Statue Vandalized on Eastbank Esplanade,” kgw.com, accessed May 19, 2020, https://www.kgw.com/article/news/local/vera-katz-statue-vandalized-on-eastbank-esplanade/283-323141683. ${ }^{46}$ Aimee Green | The Oregonian/OregonLive, "Jeremy Christian Guilty on All Counts in MAX Stabbings Trial, Including Murder and Hate Crimes,” oregonlive, February 21, 2020, https://www.oregonlive.com/news/2020/02/jeremy-christian-guilty-on-all-counts-in-max-stabbings-trial.html.
} 
the education and memorialization of the Holocaust, as institutions such as the Oregon Jewish Museum and Center for Holocaust Education work to reach more Oregonian students than ever. While antisemitic voices may be heard, they will continue to be overshadowed by a city that supports its tens of thousands of Jews who continue to choose Oregon as their home.

By the time the Oregon Holocaust Memorial opened to the public, around one million dollars had been put into the project, with tens of thousands more expected to be spent for upkeep across the years. Once built, the Holocaust memorial had taken more resources and time than the survivors who first came together for the sake of memory could have ever imagined. When OHSRF envisioned a memorial, as was their main pursuit, the cost was originally estimated at around $\$ 50,000 .{ }^{47}$ However, that price would increase twenty folds in the eight years of bureaucracy that ensued before ground was broken in Washington park. In December of 2003, the OHMC sent out a letter announcing the exciting news that the city had issued the necessary permitting for construction to begin in the coming year after an "eight-year delay." The pre-construction total needed came to $\$ 877,000 .{ }^{48}$ The price of the memorial was driven higher as more people became both concerned with the project or interested in the memorialization, and in some way staked a claim based on their memory of the Holocaust. Opposition from the Arlington Heights neighborhood created a significant amount of the delay. As disgruntled neighbors in a wealthy neighborhood, they were unable to change the outcome of the memorial. But crucially, they raised the price of memory through their spending on a lawsuit to try to avoid sharing space with the history of the Holocaust. For many reasons, some people took a stand against the memorial; rarely with antisemitic views, but often with misconceptions

\footnotetext{
47 "Letter - OHSRF and AJC."

48 "Financing the Memorial,” 2003, ORG 48 Box \#1, OHM Series I: Admin-Correspondence:OHMC (1996-2012 not inclusive), OJMCHE.
} 
of the Holocaust as a solely Jewish event, and concerns about parking. At the end the total cost of constructing the memorial was $\$ 1.2$ million dollars. ${ }^{49}$

The cost of the memorial was not the main concern of those who dedicated years to seeing their dream become a reality. Survivors and their families who set out on a journey of public memorialization for their murdered relatives always accepted that the memorial would come at a financial cost. What they would not accept however was the perspective held by a small but loud minority in the community, that the memorial was a Jews-only mission and a sign of Jewish supremacy. This perspective denotes an extreme view of Holocaust memorialization. The survivors themselves had to deal with perspectives that cast out their experiences from public memory in addition to the more severe and often racist perspectives during their lifetimes. These perspectives are based either in some part or in whole on antisemitism. Antisemitism in itself relies on an inaccurate understandings of historical realities which allows for discrimination. The public collective memory of the Holocaust does not invite in distorted recollections of history, and although such misconceptions are shared by fewer people, those memories of the Holocaust are still real. The memory of the Holocaust as only a Jewish event and as independent from Oregonian history are both erroneous recollections that live on within some Oregonians but have not been permitted into a collective memory of the Holocaust. While discriminatory comments are fringe, they are relevant given the need to defend the memory of the Holocaust at every turn so that it represents the truth for future generations. To recognize discrimination and to educate against it is a crucial step to keep distorted memories from becoming acceptable recollections.

\footnotetext{
49 “Newspaper Articles Series IV: Clippings,” 2003 - 2005, Org 48 Oregon Holocaust Memorial, Box \#11 Series IV: Clippings (1995 -2009).
} 
Despite many hurdles beginning with their persecution in Europe, survivors were able to establish a memorial that they are proud of and that the community is fortunate to have as an educational resource. Throughout the process, survivors and supporters were aware of the perspectives that were in opposition to the memorial. Thus, the significance of the first Holocaust memorial for the millions of people in the Pacific Northwest, is not lost on them. Soon after the memorial opened, survivors and members of OHMC, Eva and Les Aigner, wrote to a fellow coalition member to share the positive experiences and sentiments they have had at the site of memory.

"Les and I are visiting the memorial quite frequently and each time we are at the site we are counting our blessings that we overcame so many obstacles in the long ten years, and as a team effort we have been able to gift the community and the survivors with a beautiful, meaningful and contemplative memorial.”50

As Eva and Les reflect, they show no signs of bitterness towards those who got in the way of commemorating their murdered family. To them, perspectives that vied with the representation of their true experiences were just "many obstacles" on their long and tiring journey. The eight survivors who originally sought memorialization brought to the project their remarkable ability to persevere against the odds, which undoubtedly helped them to accomplish their goal of the Oregon Holocaust Memorial. With the memorial came the collective memory of the Holocaust, which Jewish survivors found themselves in a position to publicly produce due to their acceptance into Portland society. The created collective memory of genocide allows the memorial to be both an educational tool, and a commemorative site, as it tells a concise story for the viewer which is embedded with the perspective of survivors and themes of deportation and

\footnotetext{
50 “Letter - Eva and Les Aigner Reflect on Memorial,” 2004, \#48 Box \#4, OHM Construction, Construction: Dedication, OJMCHE.
} 
annihilation. From Eva and Les’ account, OHSRF's original objective, to aid in commemorating the memory of the Holocaust through memorialization for survivors and their families, has been achieved. When the Oregonian Holocaust survivors are gone, their memories will reside in the memorial in Washington Park for those who come next. But for the last precious years that survivors remain with us, we will try to learn what we can and watch them grieve and rejoice in a memorial made for them, by them. It is there that they can remember their beloved families and find a moment of solace after everything they have been through. They deserve nothing less. 


\section{Bibliography}

Primary sources

“Design of the Oregon Holocaust Memorial Garden,” 1999 \#48 Box \#4, OHM Construction, Construction: Design Team.

“Financing the Memorial,” 2003. ORG 48 Box \#1, OHM Series I: AdminCorrespondence:OHMC (1996-2012 not inclusive). OJMCHE.

Gragg, Randy. "Savinar: Interviews with Relatives Part of the Design.” The Oregonian. April 9, 2003. OJMCHE Archive.

Greenstein, Miriam. "Return To Auschwitz.” In In The Shadow Of Death: A Young Girl's Survival in the Holocaust, 112-17. Portland, OR: Press-22, 2010.

“Inscription Progress Report.” OHMC, 1998. Org 48 Oregon Holocaust Memorial, Box \#5 Series II: Construction (1992-2004): Inscription Approvals.

"Letter - Are Jews Better or More Important than Other Ethnic Groups? An Open Letter to the Oregon Holocaust Memorial Coalition, the City Council and Others.,” 1998, ORG 48 Box \#1, OHM Series I: Admin-Correspondence: Letters in Opposition, OJMCHE Archive.

“Letter - Eva and Les Aigner Reflect on Memorial,” 2004. \#48 Box \#4, OHM Construction, Construction: Dedication. OJMCHE.

“Letter - Judith Kahn,” 1995, Org 48 Oregon Holocaust Memorial, Box \#3 Series II: Construction, Construction: Agreements., OJMCHE.

“Letter - Nussbaum.” (Nussbaum, 1998) Org 48 Oregon Holocaust Memorial, Box \#5 Series II: Construction (1992-2004): Inscription Approval.

“Letter - OHSRF and AJC,” 1995. Org 48 Oregon Holocaust Memorial, Box \#3 Series II: Construction, Construction: Agreements. OJMCHE.

“Newspaper Articles Series IV: Clippings 2003 - 2005,” n.d. Org 48 Oregon Holocaust Memorial, Box \#11 Series IV: Clippings (1995 -2009).

“OHSRAF Concepts for Artists and Architects,” n.d. \#48 Box \#3, OHM Construction, Construction: Art Committee. OJMCHE.

Robinson, Leland. “Letter - Robinson,” 2004. Org 48 Oregon Holocaust Memorial, Box 
\#5 Series II: Construction (1992-2004): Inscription Approvals.

\section{Secondary Sources}

Bergen, Doris L. The Holocaust: A Concise History. Rowman \& Littlefield, 2009.

David Cohen, "Elie Wiesel, Holocaust Survivor, Activist and Nobel Peace Prize Winner, Dies at 87,” POLITICO, accessed May 21, 2020, https://www.politico.com/story/2016/07/eliewiesel-holocaust-survivor-activist-and-nobel-peace-prize-winner-dies-at-87-213655.

Eisenberg, Ellen. Embracing a Western Identity: Jewish Oregonians, 1849-1950. Corvallis, OR: Oregon State University Press, 2015.

Jelin, Elizabeth. "Memory in the Contemporary World.” In State Repression and Labors of Memory, 1-7, 2003.

- "What Memories Are We Talking About?" In State Repression and Labors of Memory, 8-25, 2003.

Marcuse, Harold. "Holocaust Memorials: The Emergence of a Genre.” The American Historical Review 115, no. 1 (2010): 53-89.

Oregonian/OregonLive, Aimee Green | The. "Jeremy Christian Guilty on All Counts in MAX Stabbings Trial, Including Murder and Hate Crimes.” oregonlive, February 21, 2020. https://www.oregonlive.com/news/2020/02/jeremy-christian-guilty-on-all-countsin-max-stabbings-trial.html.

Robinson, Leland. "Letter - Robinson,” 2004. Org 48 Oregon Holocaust Memorial, Box \#5 Series II: Construction (1992-2004): Inscription Approvals.

Tabarovsky, Izabella. "Auschwitz Cannot Be Only Pillar In Holocaust Memory - The Forward,” June 12, 2019. https://forward.com/opinion/425672/not-all-jews-were-killedin-concentration-camps-during-the-holocaustwe/?fbclid=IwAR2BqIC76e2HLtfJcxjntvjYPbqbbggFZ9MxRTktnOToxdasf16rkAulXqc

kgw.com. "Vera Katz Statue Vandalized on Eastbank Esplanade.” Accessed May 19, 2020. https://www.kgw.com/article/news/local/vera-katz-statue-vandalized-on-eastbankesplanade/283-323141683.

Young, James E. “America: Memory and the Politics of Identity.” In The Texture of Memory: Holocaust Memorials and Meaning, 283-349. Yale University, 1993. 